International Journal of Managing Value and Supply Chains (IJMVSC) Vol.5, No. 2, June 2014

\title{
STUDY ON THE ECONOMIC IMPACT OF EMPLOYMENT SMALL BUSINESSES LOANS UNDER THE FAMILY RELIEF COMMITTEE (CASE STUDY CITY GILANGHARB)
}

\author{
${ }^{1}$ AMENEH MALMIR ${ }^{1} \&$ GHODRATOLLAH IVANI ${ }^{2}$ \\ ${ }^{1 \& 2}$ Department of Management, Islamic Azad University, malayer, malayer, Iran
}

\begin{abstract}
Job creation is undeniable importance of creating economic stability issue. Greater attention to the issue of population can increase employment and general welfare of society in the development and reduction of poverty and unemployment. Since one of the objectives of the Charity to empower patients, particularly in economic stability and jobs and alleviate poverty and unemployment, employment and self-sufficiency in agricultural and livestock projects of service. Given the importance of employment Charity projects, particularly in agriculture, livestock and has served on the top of their agendas. The study was conducted in the same relation to loans with the aim of stabilizing the economy and employment Impact on small businesses covered by the family of the Imam Khomeini Relief Committee Gilangharb city. The study of the nature, quantity and type of research as applied to the data collection method - correlation. The population consisted of 380 households Self-Sufficiency Project Joint Relief Committee of clients that have reached the stage of self-reliance and financial independence. The sample size was determined using Cochran's formula, 75 households were selected using stratified random sampling method. The results showed that four variables' experience in the design, facilities and equipment required, and the extent of participation by family members reinvestment "These variables had the greatest effect on the success of agricultural self-sufficiency plans, clients are Gilangharb Relief city..
\end{abstract}

\section{KEYWORDS}

self- sufficiency plans, loans, employment, empowerment, clients Relief Committee.

\section{INTRODUCTION}

The poverty ominous phenomenon that involves human beings and human societies is one of the important issues. Industrialization was felt that this issue will be resolved, but after Industrial Revolution in most countries migration from rural to urban areas was further increased poverty and inequality, and makes no Stability an unprecedented social, cultural and political and consequently the economy. The Country Iran is also no exception failed in recent years due to the lack of vision in general and the lack of a strategic plan and implementation plan to fifth, as well as biased partisan descriptive politicians and statesmen, and not the overall policy of economic Article 44 of the constitution and lack Regarding the private sector, poverty and inequality in our society. The poverty, unemployment and migration from rural to urban problems, one of the concerns of officials. Poverty is a sign of underdevelopment, economic, social and cultural preceding political stability, social cohesion, economic as well as physical and mental health community threatens. In further studies and research studies have considered the main cause of poverty, unemployment and employment stability, it also introduces the key to poverty. The effects The poverty, reduced manufacturing activity and declining purchasing power and income community. We left our country because of war and international sanctions heavily involved in this phenomenon. 
Empowerment, job stability : enabling and sustaining jobs created can also the following expression:

Step One : The aid debate is gifted survey also identified the ability of individuals to their present employment the first step towards realizing the objectives of the work area and already have over 800 thousand people and talent step that can be done.

Second step : the training because you can easily train clients the necessary skills to enter the job market and be profitable economic activity so seriously Topics Education committee will follow and objects.

Step Three : Putting provide suitable facilities without interest ( financial aid ) with a repayment period of six years ( annual installments for projects in agriculture and animal husbandry, and monthly service plans ) as well as the potential created by the government and other aid organizations and the resources bank loan and notes

Step Four : Monitor employment projects including the enforcement of the insurance proposals by technical experts and observers may be an important factor in empowering and sustaining jobs is

Fifth step : Marketing the Business Assistance Center, which is responsible for creating seasonal fairs, specialized, provincial and weekly to share craft projects ( carpet weaving, carpet weaving, carpets , ... ) Ian client

\section{Theoretical framework}

Theoretical model or theoretical framework of the research work plan for how to identify the variables and their relationships to solve problems or determinable is unknown and ultimately the knowledge of. Theoretical model or map of route logical and organized research and exploratory research effort aimed at achieving research shows (Hafznya, 1389). Mentioned in the literature of the subject of this study, as a framework and as summarized in Table (1-1).

Table (1-1): Theoretical Framework Research

\begin{tabular}{|l|l|l|l|}
\hline The results & title & Year & $\begin{array}{l}\text { Investigator } \\
\text { / researcher }\end{array}$ \\
\hline $\begin{array}{l}\text { Micro-credit major contribution to } \\
\text { poverty alleviation and sustainable } \\
\text { national and local institutional } \\
\text { development }\end{array}$ & $\begin{array}{l}\text { Role of microcredit on } \\
\text { empowerment and job } \\
\text { creation }\end{array}$ & 2005 & $\begin{array}{l}\text { Azkia and } \\
\text { imani }\end{array}$ \\
\hline $\begin{array}{l}\text { One important strategy for } \\
\text { eliminating poverty, women and lead } \\
\text { them toward productive and income- } \\
\text { generating activities, which enable } \\
\text { them to play a major role in the } \\
\text { production of agricultural products } \\
\text { and sustainable development. }\end{array}$ & $\begin{array}{l}\text { Impact of microcredit on the } \\
\text { economic empowerment of } \\
\text { households hom heads of }\end{array}$ & 2007 & $\begin{array}{l}\text { Najafi } \\
\text { Talib }\end{array}$ \\
\hline $\begin{array}{l}\text { Individual characteristics such as as } \\
\text { education and skills, has had the } \\
\text { greatest impact on the empowerment } \\
\text { of rural women. }\end{array}$ & $\begin{array}{l}\text { Understanding the review } \\
\text { committee for the } \\
\text { empowerment of female- } \\
\text { headed household }\end{array}$ & 2006 & $\begin{array}{l}\text { Jafari } \\
\text { Mhtash }\end{array}$ \\
\hline
\end{tabular}


International Journal of Managing Value and Supply Chains (IJMVSC) Vol.5, No. 2, June 2014

\begin{tabular}{|l|l|l|l|}
\hline $\begin{array}{l}\text { Social capital of individuals and } \\
\text { groups are affected by poverty, } \\
\text { deprivation and poverty have a } \\
\text { negative impact on social capital so } \\
\text { that the fields necessary to promote } \\
\text { corruption and criminality creates. }\end{array}$ & $\begin{array}{l}\text { Poverty and social capital in } \\
\text { city committee }\end{array}$ & 2007 & $\begin{array}{l}\text { Zahedi and } \\
\text { others }\end{array}$ \\
\hline $\begin{array}{l}\text { Employment and empowerment is a } \\
\text { key factor in poverty reduction. Also, } \\
\text { low skills in reading, writing, mental } \\
\text { and physical issues, debt and debt- } \\
\text { related employment and } \\
\text { empowerment. }\end{array}$ & $\begin{array}{l}\text { Employment } \\
\text { empowerment of rural }\end{array}$ & 2003 & Webster \\
\hline $\begin{array}{l}\text { Provide financial services to the poor } \\
\text { to increase household income, reduce } \\
\text { unemployment, improve living } \\
\text { standards, savings, increased self- } \\
\text { esteem. }\end{array}$ & $\begin{array}{l}\text { The effect of empowering } \\
\text { the poor }\end{array}$ & 2001 & Robinson \\
\hline $\begin{array}{l}\text { Reduce poverty, promote human } \\
\text { grandeur, equality and justice, poor } \\
\text { access to credit and skills, Qdrtdhy } \\
\text { and increase the confidence of the } \\
\text { policies and goals of empowerment. }\end{array}$ & $\begin{array}{l}\text { Poverty alleviation through } \\
\text { microcredit }\end{array}$ & 2002 & Khander \\
\hline $\begin{array}{l}\text { Microcredit can increase family } \\
\text { income and poor means to protect } \\
\text { against shocks to Mashshan rulers. }\end{array}$ & $\begin{array}{l}\text { Microcredit and poverty } \\
\text { reduction }\end{array}$ & 2004 & $\begin{array}{l}\text { Johnson\& } \\
\text { Rogaly }\end{array}$ \\
\hline
\end{tabular}

\section{Methodology :}

The study of the nature of the data, one is a little research. Since the results of this study can be used in planning and employment policies at national or provincial level, applied research, applied also in terms of data collection or control variables, the present study descriptive correlation.

\subsection{Hypotheses :}

Hypotheses based on the literature reviewed in this research is theoretical and based on guesswork relationships between independent and dependent variables, the correlations are presented below .

Hypothesis 1 : The relationship between educational level of the patients there was a significant success and self-sufficiency plan .

Hypothesis 2 : the amount of loans received by the client and the successful employment schemes have a meaningful relationship .

Hypothesis 3 : the level of income and employment initiatives and their success is a meaningful relationship .

Hypothesis 4 : between independence and success of client engagement is a meaningful relationship . 
International Journal of Managing Value and Supply Chains (IJMVSC) Vol.5, No. 2, June 2014

Hypothesis 5 : the experience in the design and successful initiatives employed by the client , there is a significant relationship

Hypothesis 6 : the skill and success of the design work on the project by the client, there is a significant relationship

Hypothesis 7 : the interest of clients successfully plan, employment by occupation, there is a significant relationship

Hypothesis 8 : among the facilities required and the successful employment schemes have a meaningful relationship .

Hypothesis 9 : the timely payment facility to help job seekers and designs, there is a significant relationship

Hypothesis 10 : International competition and success of Project employment schemes, there is a significant relationship

Hypothesis 11 : The relationship between the participation of family members of patients there was a significant success in employment schemes .

Hypothesis 12 : the visitor and employee monitoring committee plans to self -employed clients plan for success is a meaningful relationship.

The research model:2-5

A research model charts for variables derived from the theoretical framework (Earth, 2008). Conceptual model reflects the purpose of the research, suggest topics, angles and dimensions of the problem that must be studied. The conceptual model of visual models and flow charts that location, sequence, communication shows the variables and structure variables in organic and cohesive devices reflects (Hafznya, 2011). This model has been shown to influence the dependent variable of the independent variables. 


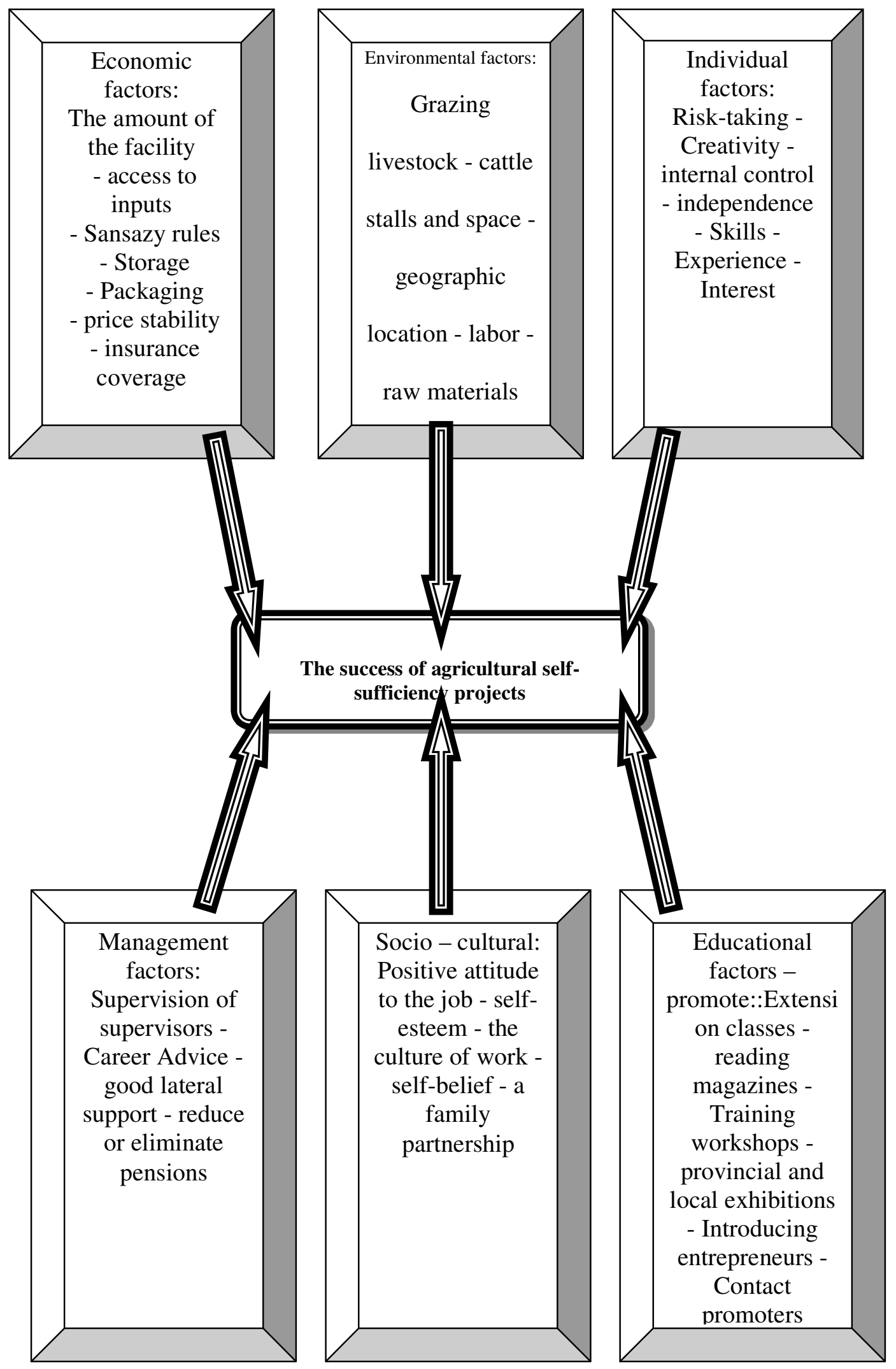


The statistical population included all households in the city Gilangharb clients Relief Committee, which is typical of the projects and into self-sufficiency and financial independence have been used. Studies have been conducted in Population volume of agricultural selfsufficiency plan, which has 380 member families.

Municipalities are scattered Gilangharb city (city committee Gilangharb Statistical Report, 2012). Considering that it is possible to realize it possible for the whole society, is the number of samples that are the properties of population.

The main task of sampling, selecting a sample of the Population using proper techniques so as to ensure that samples are representative of the Population as possible to avoid the bias in the sample selection.

Table (1-2): Determine the sample size is proportional to population size

\begin{tabular}{|l|l|l|}
\hline Sample & Population & Rural district \\
\hline 10 & 55 & Govavr \\
16 & 87 & Haydarieh \\
9 & 43 & Chelle \\
13 & 64 & divan \\
13 & 63 & Deira \\
14 & 68 & Gvrsfyd \\
\hline 75 & 380 & sum \\
\hline
\end{tabular}

Data collection methods and data in the present study, a combination of field study techniques and study of literature . Data collection also included questionnaire. The researcher, for purposes of research, along with field study questionnaire, library research using secondary sources, such as research papers, English and Persian, publications and taking notes from material collected in connection with consideration of research put. While the data were combined with instruction Civil Relief Committee has been enriching.

The main tool is a questionnaire survey method to investigate the presence of the subjects completed the ratio of extracted data, action was taken. Searching, gathering information on the World Wide Web, internal and external related to the subject sites, about was searched. of documents and written sources, this method refer to the documentation centers and libraries, researching relevant information was collected.

Structured questionnaire was the main instrument for this research. Main questionnaire included the following:

Table (1-3): main questionnaire item number

\begin{tabular}{|c|c|c|}
\hline Issue & Questionnaire topics & Item number \\
\hline 1 & $\begin{array}{l}\text { Characteristics and individual factors affecting the success of self- } \\
\text { sufficiency projects }\end{array}$ & \\
\hline 2 & $\begin{array}{l}\text { Environmental variables affecting success in self-sufficiency } \\
\text { programs }\end{array}$ & $\begin{array}{l}16 \\
5\end{array}$ \\
\hline 3 & $\begin{array}{l}\text { Economic variables affecting the success of self-sufficiency } \\
\text { projects }\end{array}$ & 8 \\
\hline 4 & $\begin{array}{l}\text { Educational variables - overall impact on the success of self- } \\
\text { sufficiency projects }\end{array}$ & $\begin{array}{l}6 \\
4\end{array}$ \\
\hline 5 & $\begin{array}{l}\text { Social variables - cultural influences on the success of self- } \\
\text { sufficiency projects }\end{array}$ & 6 \\
\hline
\end{tabular}


International Journal of Managing Value and Supply Chains (IJMVSC) Vol.5, No. 2, June 2014

\begin{tabular}{|l|l|l|}
\hline 6 & $\begin{array}{l}\text { Management variables influence the success of self-sufficiency } \\
\text { projects } \\
\text { Variables to assess the success of self-sufficiency plan }\end{array}$ & \\
\hline
\end{tabular}

A questionnaire was used to address the problem, objectives and hypothesis testing. The questionnaire has been developed using literature, theoretical foundations and conceptual frameworks.

\subsection{The validity of measurement:}

This research is used to determine the validity of content validity. This means that it is offering a number of experts and specialists, their views on the validity of the questionnaire was to obtain the views of the corrective actions they took to prove validity of the investigation.

\section{4 instrument validity}

The reliability of the pretest was conducted among 30 patients. and then calculated Cronbach's alpha coefficient for each part separately . accordingly, some questions were deleted or modified and the final Cronbach's alpha coefficient for the questionnaire was 83/0 respectively, which indicates the desired final research tool.

\section{4 - Data Analysis}

In this section, according to hypotheses, and depending on the level of variables (nominal, ordinal, interval), the appropriate correlation coefficients, such as Pearson and Spearman regression, the dependent variable explained by the independent variables were used to determine the percentage.

\section{5 - Results}

In this study the researcher tried to researchers, planners and those interested in the study of methods, processes and results, applications for employment, economic empowerment, and sustainability of small businesses and relief organizations now familiar approaches Homepage. And ways to overcome unemployment and consequent poverty reduction and social issues that arise from the society, especially in its goal . However specified that the work is the essence of health and vitality of the human effort that entails no doubt that both he and the material world around decline, and the not said. Employment in today's society it is considered serious enough that as an indicator in the assessment of development in communities will be considered and in most cases unemployment regarded as, the poverty line crossing.

Gains resulting from planned employment creation powerful aid of collaboration with clients by their target population is as follows:

1 - employment, social status grounds.

2 - employment, reduce poverty and solve social problems arising from the communities.

3 - deprived of employment will lead to consumer households become fully productive households.

4 - employment, GDP will increase and strengthen the foundation of national security.

5 - employment is considered as a multi-factor and the mental health of individuals. 
6 - employed, provides prevents the migration of villagers and residents of small towns to big cities.

7 - employment, to reinforce a sense of self-esteem and confidence among the people, under the auspices.

8 - employment, family bonds are backed ourselves cause.

9 - employment, the family is supported by the stability of crafts, especially small businesses.

\section{6 - Summary and conclusions:}

The poverty and unemployment are the most important issues in the country. An important feature of a dynamic economy, social justice and healthy. So that planners for social justice, to reduce inequalities through the development and implementation of various programs and develop the positive aspects of deprivation are developed. Basically desire to eliminate employment and unemployment in the most important way to overcome poverty, reduce inequalities and social injustices. Therefore, the committee aims to empower patients, especially in the economic, employment and self-sufficiency projects in various manufacturing and service sector employment stability. The investment in these sectors to create more job opportunities in different areas, especially rural and rural to urban migration will stop. (Soltani, 2004).

Relief Committee, in addition to increased financial self-sufficiency projects by client, cause self-esteem and self-reliance, hard work to create a culture of empowerment and creating sustainable employment among them. Regarding the issue of speech, poverty, unemployment and consequent economic and social problems as well as a cultural issue that many researchers have dealt with many ways to solve and improve the status quo have provided the ideal situation. But it must be accepted with respect to the development of rapid shifts of countries and competition for resources and monopolies dominate the fast-growing countries by colonialism and capitalism, third world countries, have suffered serious damage. The Country Iran was outside the rule addition and reconstruction after the war, in addition, however no long-term political and government decision-making moment in the economy in recent years have led to high rates of unemployment and inflation, especially among vulnerable and low-income communities and community outreach sponsored by this committee to address poverty and unemployment is a major issue.

As well as the planning and execution of regular employment and empower small businesses have been able to identify talented individuals, families in the employment field. The material and spiritual resources and motivation and to provide the necessary support and close monitoring experts recorded the amount of time available to process implemented by the relevant authorities, under the protection of consumption and consumerism family families causing converts so family there is no longer need for cash assistance and livelihood support to this institution. Attempt in addition to creating jobs and improving our economy and culture has contributed to the reduction of unemployment and poverty and social damage caused to the state and country. Study of nature, little research is a retrospective. Considering that the results could be used by policy makers and managers and those in charge of the provincial or national level should be engaged in applied research category is the data collection descriptive - correlation. 
International Journal of Managing Value and Supply Chains (IJMVSC) Vol.5, No. 2, June 2014

\section{Resources}

1. Untitled (1982), Statutes of the Imam Khomeini Relief Committee (RA )

2. Ghaedi , AS . ( 2009), the fourth five-year development plan and self -employed clients Imam Khomeini Relief Committee (RA ), published by the Bureau of Monitoring and Assessment of Relief Committee .

3. Ghaedi , AS . (2008), the administration of employment and entrepreneurship ( creating jobs ), Tehran, Second Edition, published by Department of Employment and Self- Sufficiency Relief Committee .

4. Old Dizaj Ave . (2001), examining the economic activities of Imam Khomeini Relief Committee (ra ) on some macro- economic variables .

5. Set the rules and practice in the Imam Khomeini Relief Committee (RA ). (2003 ), published by the Center for Higher Education - Applied.

6. Pour Askari , A. and Bagheri , A. . (2011 ), the role of micro-credit and banking Civil Relief Committee on client empowerment and job creation (case study city Spring Conference for Sustainable Rural Development .

7. Mania Ashtiani, K. . (2009), this article examines the role of the Committee on harm reduction and social assistance, with emphasis on empowerment, internet article visible through the address :

8. Anonymous (2009 ), drafted fifth Entrepreneurship and Career Development, Tehran, Press Relief Committee Vice -sufficiency and employment center.

9. Hope , M. , et al Department of Relief Committee . (2011) model, enabling clients to focus on jobs Relief Committee , National Conference of Jihad Economic Empowerment Approach , published by the Center for Education and Research

10. KIA , M \& Imani , AS . (2005), the role of microcredit on empowerment and job creation.

\section{Authors}

Ameneh Malmir. Lecturer

Islamic Azad University, Malayer Branch, Iran

Ms Ameneh Malmir holds PhD in Management of Human Resources from Islamic Azad University, Iran. She is serving as lecturer at Islamic Azad University, Malayer Branch, Department of management, Malayer, Iran. Ms Aminah is a young and enthusiastic researcher in the disciplines of HR, management, organization studies, and leadership. She authored various research papers in her areas of expertise, and are published in international peered review journals.

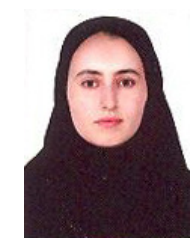

